\title{
Neuroprotective Effect of Xylopia Aethiopica Seed on Lead-Induced Injury on the Cerebral Cortex of Male Wistar Rat
}

\author{
Chinna Nneka Orish ${ }^{1,}$, , Samuel Sotonye George ${ }^{1}$, Eberechi Wogu ${ }^{1}$, \\ Anthoneth Ndidiamaka Ezejiofor ${ }^{2}$ \\ ${ }^{1}$ Department of Anatomy, Faculty of Basic Medical Science, University of Port-Harcourt, Port Harcourt, Nigeria \\ ${ }^{2}$ African Centre of Excellence for Public Health and Toxicological Research, University of Port Harcourt, Port Harcourt, Nigeria
}

\section{Email address:}

chinna.orish@uniport.edu.ng (C.N. Orish)

${ }^{*}$ Corresponding author

\section{To cite this article:}

Chinna Nneka Orish, Samuel Sotonye George, Eberechi Wogu, Anthoneth Ndidiamaka Ezejiofor. Neuroprotective Effect of Xylopia Aethiopica Seed on Lead-Induced Injury on the Cerebral Cortex of Male Wistar Rat. International Journal of Psychological and Brain Sciences. Vol. 6, No. 1, 2021, pp. 7-12. doi: 10.11648/j.ijpbs.20210601.12

Received: December 27, 2020; Accepted: January 15, 2021; Published: March 10, 2021

\begin{abstract}
Background: Lead $(\mathrm{Pb})$ is one of the most common environmental toxicants, exposure to which can cause significant neurotoxicity and an associated decline in brain function. Plant derived products with antioxidants activity are useful in reducing lead induced neurotoxicity. This study investigated neuroprotective and antioxidant properties of the aqueous Xylopia aethiopica against lead -induced neurotoxicity in male Wistar rats. Methods: Six groups of six weightmatched animals each, were used for the study. The group 1 (normal control) was treated with distilled water and group 2 (toxic control) with lead acetate at the doses of $50 \mathrm{mg} / \mathrm{kg} \mathrm{b}$.wt, whereas group 3 received only Xylopia aethiopica $40 \mathrm{mg} / \mathrm{kg}$ only, groups 4,5 , and 6 were simultaneously treated with lead $(50 \mathrm{mg} / \mathrm{kg}$ b.w.), and $40 \mathrm{mg} / \mathrm{kg}, 80 \mathrm{mg} / \mathrm{kg}$, and $160 \mathrm{mg} / \mathrm{kg}$ of Xylopia aethiopica respectively The treatment was administered orally for 42 days. Their biochemical and histopathological investigations were carried out following animal sacrifice at the end of the study period. The neuroprotective effect of Xylopia aethiopica was assessed by measuring redox status (malondialdehyde), enzymatic antioxidant activities (Superoxide dismutase, Catalase, Glutathione peroxidase and glutathione reductase) and histopathology of the cerebral cortex. Results: The increase in the malondialdehyde, the decrease in the activity of antioxidant enzymes (Catalase, Glutathione peroxidase and reductase), and the altered histology of the brain induced neurotoxicity by lead acetate were mitigated in the brain of rats treated with Xylopia aethiopica. Conclusion: Aqueous Xylopia aethiopica has a neuroprotective role against lead - induced neurotoxicity probably mediated through its antioxidant properties.
\end{abstract}

Keywords: Neurotoxicity, Xylopia aethiopica, Antioxidant, Lead

\section{Introduction}

Lead $(\mathrm{Pb})$ is ubiquitous in the environment and toxic. Once introduced into the body, $\mathrm{Pb}$ has a wide-ranging of negative effect on many organs, and induces many biochemical, physiological, and behavioral alterations [1]. The brain is particularly susceptible to the deleterious effects of $\mathrm{Pb}$, which has been reported to induce damage to the nervous system through several direct and indirect mechanisms. Oxidative stress has been recognized to be a major indirect mechanism of $\mathrm{Pb}$ neurotoxicity [1]. The induction of oxidative stress is characterized by increased levels of reactive oxygen species (ROS) such as superoxide $\left(\mathrm{O}^{2-}\right)$ and hydroxyl $(\bullet \mathrm{OH})$ radicals, hydrogen peroxide $\left(\mathrm{H}_{2} \mathrm{O}_{2}\right)$, and lipid peroxide [1].

Medicinal plants are important sources of drug synthesis. Ksouri (2012) [2] has argued, much of the modern pharmaceutical industry is founded on compounds identified from medicinal plants discovered by native peoples and local societies. Various crude extracts and drugs of plant origin have shown promise in the treatment of a range of neurological diseases, and many studies have demonstrated 
how the antioxidant properties of natural products help to mitigate the toxicity of lead acetate Xylopia aethiopica or African negro pepper enjoys a huge patronage both in nutrition and in ethno medicine [3-5] The plant is thought to be rich in a number of physiologically and pharmacologically active agents, including volatile oils [6,7]. The seed of Xylopia aethiopica have been reported to act as antioxidant, hypolipidemic and hypoglycaemic agent [8]. Flavonoids from $X$. aethiopica have been shown to exhibit both antioxidant and anti-inflammatory properties [9]. Its antioxidant or free radical scavenging activities are considered plausible candidates for the prevention of tissue injury occasioned by lead. Antioxidant enzymes are capable of scavenging free radicals from oxidative stress thereby stabilizing the membrane. It has been found that many neurodegenerative diseases are as a result of oxidative stress which could be ameliorated by antioxidant enzymes. This antioxidant system includes, antioxidant enzymes (e.g., SOD, GPx and reductase, CAT, etc.), nutrient-derived antioxidants (e.g., ascorbic acid, tocopherols and tocotrienols, carotenoids, glutathione and numerous other antioxidant phytonutrients present in a wide variety of plant foods.

To date, however, there remain a paucity of data on the neuroprotective effects of Xylopia aethiopica on $\mathrm{Pb}$-induced neurotoxicity. The current study was therefore planned to utilize a rat model to elucidate whether Xylopia aethiopica, when pre-administered before lead acetate (LA) treatment, can ameliorate $\mathrm{Pb}$-induced neurotoxicity which will proffer a solution of designing a drug model as cheap antidote in treatment of lead poisoning.

\section{Materials and Methods}

\subsection{Plant Collection/Sample Identification}

Plant material dried seed of X. aethiopica were bought from local market in Port Harcourt, Rivers State, Nigeria. It was identified and authenticated in Department of Pharmacognosy, Faculty of Pharmacy, University of Port Harcourt, Rivers State Nigeria.

\subsection{Sample Processing and Extraction}

The dried $X$. aethiopica seed was milled into fine powder. After weighing the powder, the extract was prepared using cold maceration method thus: In $100 \mathrm{ml}$ of distilled water, 1 gram of powder was dissolved. The mixture was strained after 24 hours, pressed, filtered and stored inside in refrigerator at $4^{\circ} \mathrm{C}$. Fresh extracts were prepared every three days.

\subsection{Experimental Design}

Six groups of five weight-matched animals each, were used for the study. Group 1 was treated with distilled water and Group 2 animals received only $50 \mathrm{mg} / \mathrm{kg}$ b.w. lead acetate, group 3 received $40 \mathrm{mg}$ of Xylopia aethiopica only Group 4-6 received $40 \mathrm{mg} / \mathrm{kg}, 80 \mathrm{mg} / \mathrm{kg}$ and $160 \mathrm{mg} / \mathrm{kg}$ of Xylopia aethiopica p.o. and $50 \mathrm{mg} / \mathrm{kg}$ b.w of lead acetate orally respectively for 42 days. Animals were sacrificed $24 \mathrm{~h}$ after the last treatment. Rats were sacrificed under diethyl ether anesthesia; cerebrum was excised, rinsed clean in saline, weighed and preserved in $10 \%$ formalin for histopathological study. All the experimental procedures were performed according to the committee for the purpose of control and supervision of experiments on animals, norms and approved by the Institutional Animal Ethical Committee with clearance number UPH/R\&D/REC/04

\subsection{Antioxidant Assay}

The cerebrum was minced into small pieces and homogenized with ice cold $0.05 \mathrm{M}$ potassium phosphate buffer ( $\mathrm{pH} 7.4$ ) to make $10 \%$ homogenates. The homogenates were centrifuged at $6000 \mathrm{rpm}$ for $15 \mathrm{mins}$ at $4^{\circ} \mathrm{C}$. The supernatant was collected for the estimation of catalase (CAT) activity using hydrogen peroxide as substrate according to the method of Clairborne (Clairborne 1995) [10] Superoxide dismutate (SOD) was assayed by the method described by (Misra and Fridovich 1972) [11]. GlutathioneS-transferase (GST) was assayed by the method of Habig et al. 1974 [12]. Reduced glutathione $(G S H)$ was determined at $412 \mathrm{~nm}$ using the method described by Sedlak and Lindsay 1996. [13] Lipid peroxidation was also determined as malondialdehyde (MDA) according to the method describe by Ohkawa et al. 1978 [14] and the MDA level was calculated according to the method of Todorova et al. [2005 [15] and expressed as $\mu \mathrm{mol} \mathrm{MDA} / \mathrm{mg}$ protein.

\subsection{Histopathological Studies}

Cerebrum from all the experimental groups were fixed in $10 \%$ formaldehyde, dehydrated in graded alcohol, cleared in xylene and then embedded in paraffin. Microtome sections ( $5 \mu \mathrm{m}$ thick) were prepared from each brain sample and stained with toludine blue dye. The sections were examined for the pathological findings.

\subsection{Statistical Analysis}

The data obtained from the experiment was statistically analyzed and expressed as Mean \pm Standard deviation (SD) using SPSS (Statistical package for social sciences) and oneway analysis of variance (ANOVA) followed by post-hoc Turkey test. Values of $* p<0.05$ were considered statistically significant

\section{Results}

The neuroprotective effect of $X$. aethiopica on lead induced injury on the cerebrum in male Wistar rats is shown in Figures 1 (a-f).

The control group (Figure 1a) showed intact neuronal cells with no degeneration whereas in toxic $\mathrm{Pb}$ only treated group, there was neuronal degeneration evidenced by cytoplasmic vacuolation (Figure 1b). Group treated with $X$. aethiopica only, the neuronal cells in various layers appear intact with increase regeneration (Figure 1c). The concurrent treatment with the aqueous leaf extract of Xylopia aethiopica dose 
dependently showed neuronal regeneration in cerebral vacuolation. histology (Figure d, e and f) evidenced by reduced cell

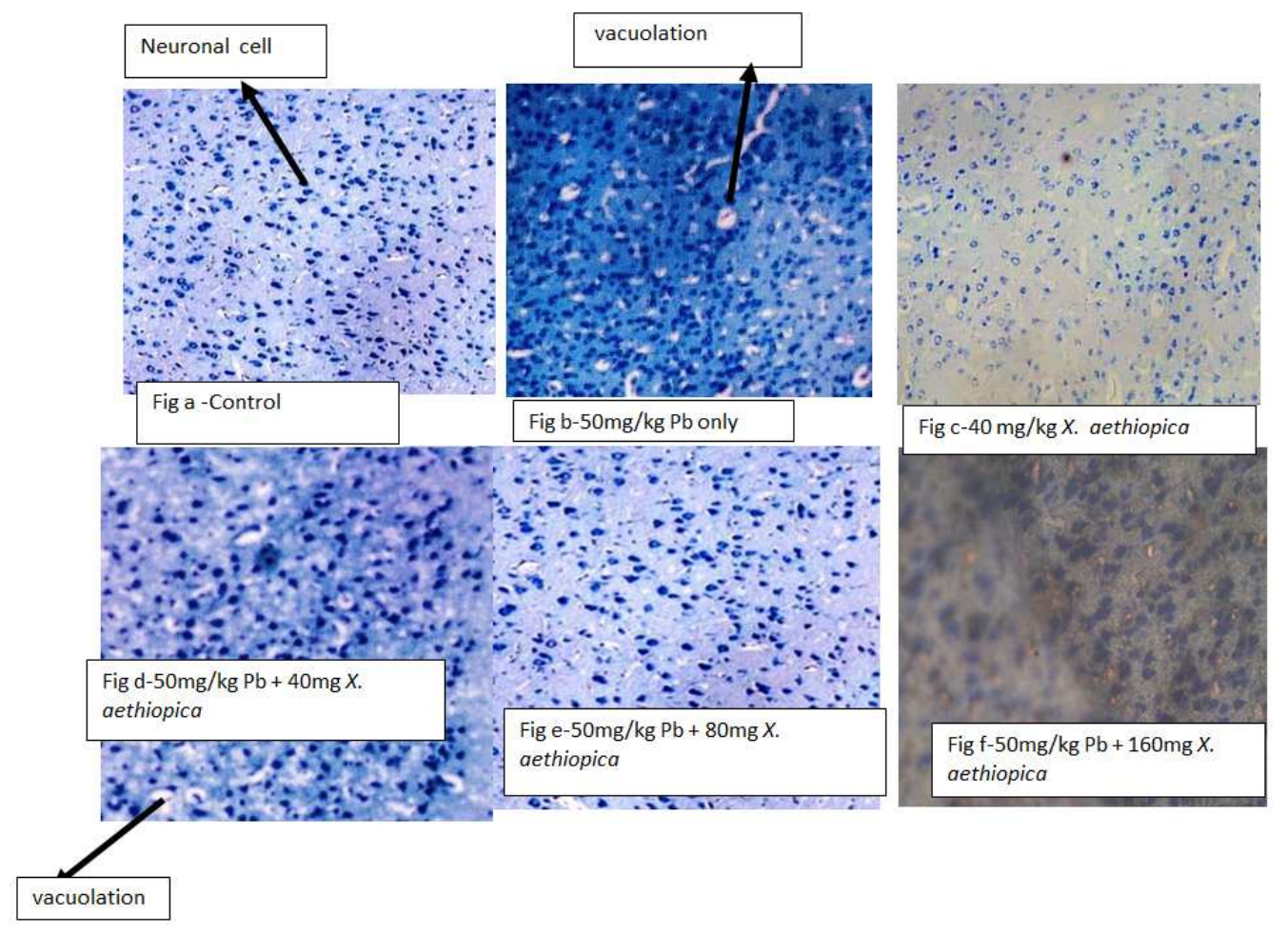

Figure 1. Effect of X. aethiopica on lead induced injury on the cerebrum in male Wistar rat.

The effect of Xylopia aethiopia on the feed intake of lead treated Wistar albino rats is shown in Figure 2. There was decrease in feed intake in Lead treated groups when compared with control

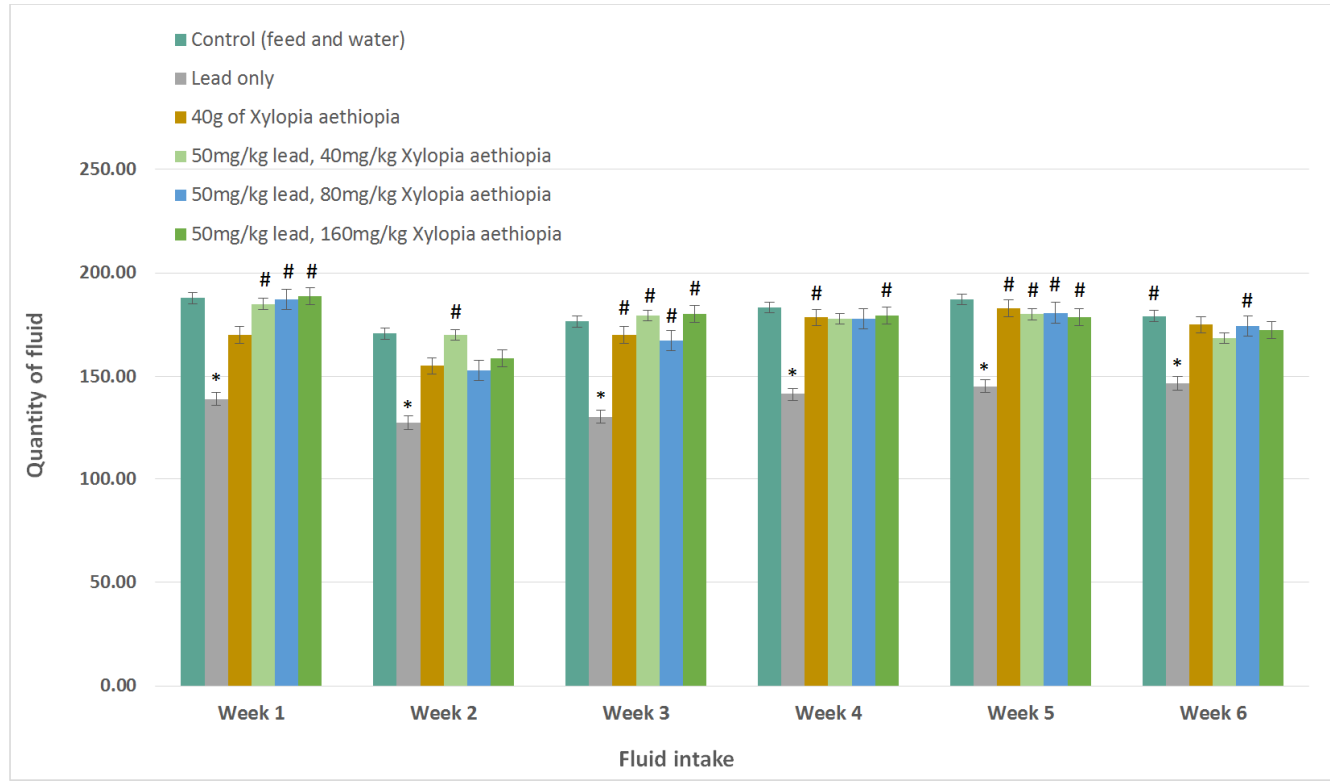

Figure 2. Effect of Xylopia aethiopia on the fluid intake of albino Wistar rats Each value represents mean \pm SD, Values marked with asterisk (*) differ significantly from control value $(* p<0.05)$ while those marked with (\#) differ significantly from lead only group $(\# p<0.05)$.

Figure 3: shows the effect of Xylopia aethiopia on the fluid intake of lead treated Wistar albino rats. There was a significant decrease in fluid intake in Lead only treated (Group 2) when compared with the control group., Groups 4-6 that received both lead and Xylopia aethiopica showed significant increase in fluid intake when compared with control. 


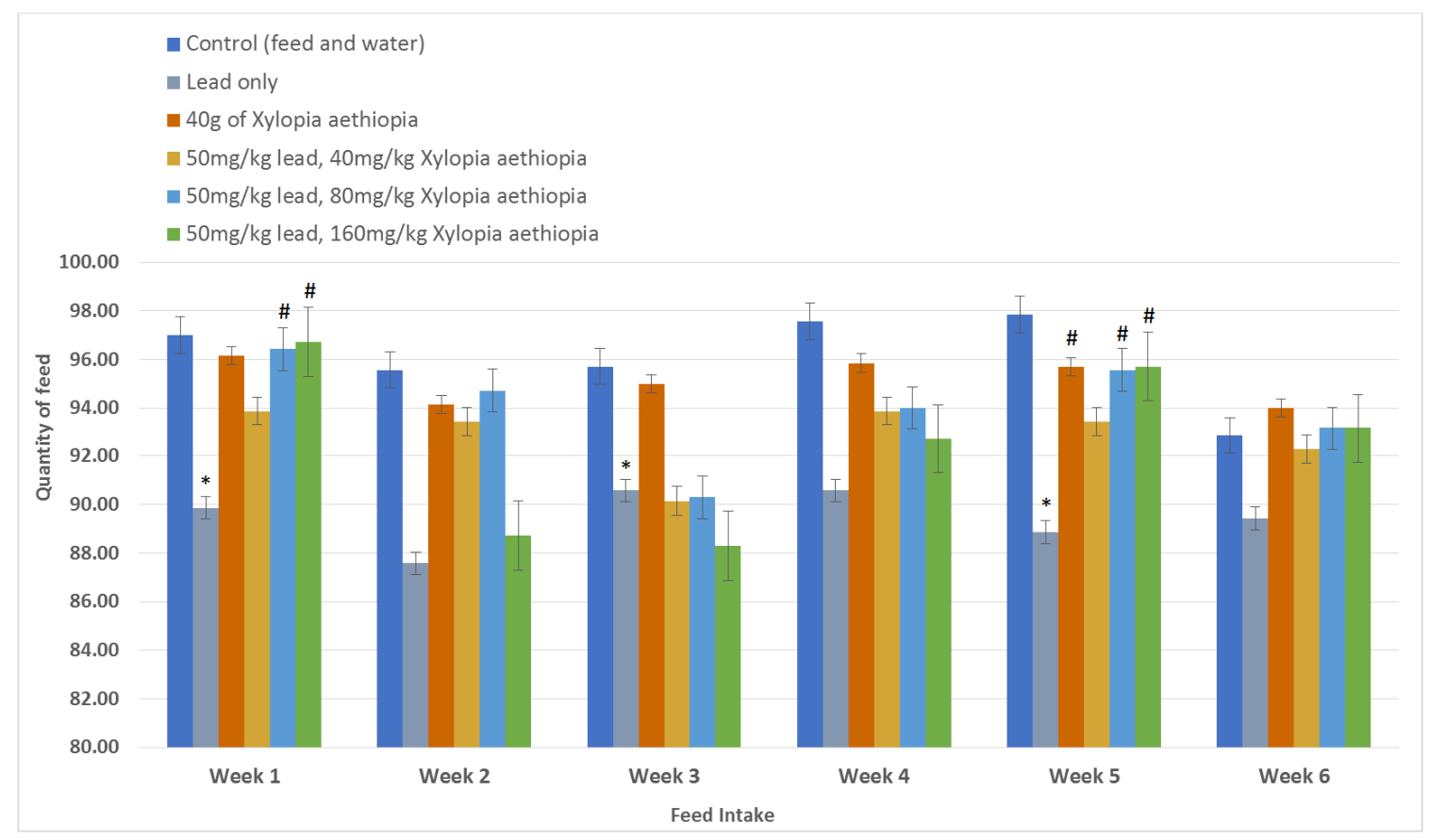

Figure 3. Bar chart showing the effect of Xylopia aethiopica on the feed intake of albino Wistar rats. Each value represents mean $\pm S D$, Values marked with asterisk (*) differ significantly from control value $\left(*^{*}<0.05\right)$ while those marked with (\#) differ significantly from lead only group (\#p $\left.<0.05\right)$.

The effect of X.a aethiopia on the oxidative stress markers of lead treated Wistar rats is shown in Figure 4. Lead treatment (Group 2, caused a decrease in antioxidant enzymes namely Superoxide dismutase (SOD), Catalase (CAT), Reduced glutathione (GSH) and Glutathione-S-transferase (GST) when compared with the normal control group, whereas Groups 4-6 that received both lead and X. aethiopica had increased antioxidant enzymes namely Superoxide dismutase (SOD), Catalase (CAT), Reduced glutathione (GSH) and Glutathione-S-transferase (GST) when compared with toxic control (lead acetate only). Lead treatment caused an increase in malondialdehyde (MDA) when compared with control, whereas Groups 4-6 that received both lead and $X$. aethiopica had decrease in malondialdehyde (MDA) when compared with control.

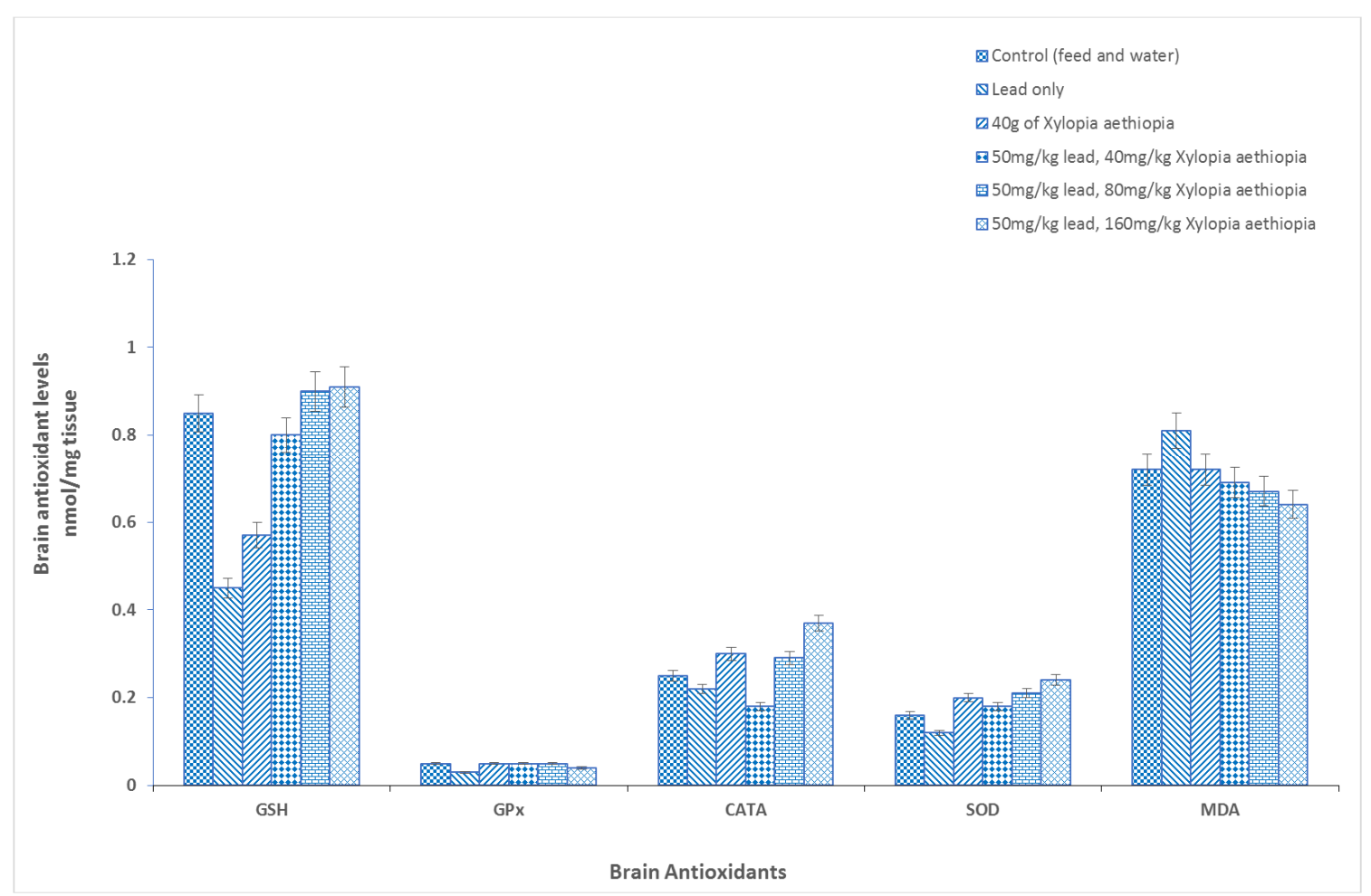

Figure 4. Effects of Xylopia aethiopica on the oxidative stress markers of Wistar rat's cerebral cortex. 


\section{Discussion}

Lead exerts some of its neurotoxic effects by promoting oxidative damage and peroxidation of the lipids in the cell membranes, thus compromising cellular functions by impairing the physicochemical properties, fluidity, and integrity of cell membranes, thereby increasing the cell vulnerability to lipid peroxidation and cell death [16]. Both animal and human studies have suggested that exposure to $\mathrm{Pb}$ is associated with increased oxidative stress and a heightened incidence of neurotoxicity. Antioxidants exert their effects via several basic mechanisms, which include: scavenging the species that initiate peroxidation, quenching singlet oxygen, chelating metals, breaking free radical chain reactions, and reducing the concentration of $\mathrm{O}_{2}$. Antioxidants exert their effects through mechanism that initiate perioxidation, chelating metals, breaking free radical chain reactions and reducing concentration of $\mathrm{O}_{2}$. As strong free radical scavengers, they can act as very effective neuroprotective agents against lead-induced oxidative stress. The presence of these phytochemicals' tannins and flavonoids in the leaf and fruit extracts of $X$. aethiopica have accounted for the antioxidant activity [17] $X$ aethiopica may be stimulating glutathione synthesis, thereby maintaining intracellular glutathione levels and scavenging reactive oxygen species [18]. In addition, it has a lot of micronutrients and can also act as metal chelators. Nutritional factors are often mentioned as important modifiers of lead metabolism and lead toxicity [19]. This intrinsic quality has attracted widespread interest in clinical nutrition and medicinal research.

Our observation of increased aldehydic by-products like malondialdehyde (MDA) by lead treatment in rat cerebral cortex and a significant decrease in total antioxidants with lead confirms the role of oxidative stress in lead induced neurotoxicity. This is consistent with earlier studies [1, 20]. Lead treatment of the rats resulted in an increase in cerebral tissue (L-MDA) levels as compared with the $X$ aethiopica extract treated groups $(p<0.05)$ and decrease in antioxidant glutathione, glutathione peroxidase, catalase and superoxide dismustase activity which had been reported by others [21-22]. Similarly, the increase in the malondialdehyde, the decrease in the activity of antioxidant enzymes (Catalase, Glutathione peroxidase and reductase), and the altered histology of the brain induced neurotoxicity by lead acetate were mitigated in rats treated with $X$ aethiopica observed in this study agree with research work of Adaramoye et al 2010 [23]. on effects of $X$ aethiopica (Annonaceae) fruit methanol extract on $\gamma$-radiation-induced oxidative stressing brain of adult male Wistar rats. There were marked neuronal vacuolation and neurodegeneration in lead treated rats. This inflammatory phenomenom was ameliorated by $X$ aethiopica in a dose dependent manner. $X$. aethiopica is a rich source of flavonoids which have been shown to exhibit both antioxidant and anti-inflammatory properties [9]
There is sparsity of information on neuroprotective effect of Xylopia aethiopica on lead induced injury of cerebral cortex, however according to research by Bolaji and Orhue 2015 [24]. on protective effect of X. aethiopica fruits extracts on carbon tetrachloride induced nephrotoxicity in rats, they found that $\mathrm{X}$. aethiopica protects kidney against $\mathrm{CCl} 4$ induced damage via antioxidant potential of the plant. This is in accordance with this study which reported that Xylopia aethiopica has neuroprotective effect against lead induced injury. Adaramoye et al 2010 [25]. also reported that Xylopia aethiopica has a protective effect on testis via its antioxidant property. This agrees with this present study too. In another study, Adaramoye et al. 2011 [26] reported that $X$ aethiopica protected Wistar albino rats from adverse effects of wholebody radiation. This is in line with this study which showed that $X$ aethiopica has neuroprotective effect

\section{Conclusion}

It can be concluded that $X$ aethiopica have a protective role against Lead $(50 \mathrm{mg} / \mathrm{kg})$-induced neurotoxicity probably mediated through its antioxidant properties at minimal dose of $40 \mathrm{mg} / \mathrm{kg}$.

\section{References}

[1] Abdel Moneim AE. Flaxseed oil as a neuroprotective agent on lead acetate-induced monoamineric alterations and neurotoxicity in rats. Biol Trace Elem Res. 2012; 148: 363370. [PubMed].

[2] Ksouri, R., Ksouri, W. M., Jallali, I., Debez, A., Magné, C., Hiroko, I., \&Abdelly, C. Medicinal halophytes: potent source of health promoting biomolecules with medical, nutraceutical and food applications. Critical reviews in biotechnology, 2012 32 (4), 289-326.

[3] Abdou HM, Hassan MA. Protective role of omega-3 polyunsaturated fatty acid against lead acetate-induced toxicity in liver and kidney of female rats. Biomed Res Int 2014. 2014 435857. [PMC free article] [PubMed].

[4] Asekun OT, Adeniyi BA. Antimicrobial and cytotoxic activities of the fruit essential oil of Xylopia aethiopica from Nigeria. Fitoterapia. 2004; 75: 368-370.

[5] Oluwatosin A, Osume O, Okiti E, Farombi Dried fruit extract from Xylopiaaethiopica (Annonaceae) protects Wistaralbino rats from adverse effects of whole-body radiation. Experimental and Toxicologic Pathology. DOI: 10.1016/j.etp.2010.05.005.

[6] Ogbonnia S, Adekunle AA, Bosa MK, Enwuru VN. Evaluation of acute and Subacute toxicity of Alstoniacongensis Engler bark and Xylopia aethiopica (Dunal)

[7] Burkhill HM. The useful plants of west tropical Africa. $2^{\text {nd }}$ Edition Royal Botanic Garden. 1985; 1: 130-132.

[8] Ameyaw Y, Owusu-Ansah E. Morpho-histological studies of two plant species used in Ethnomedicine. Journal of Herbs, spices and Medicinal Plants. 1998; 5 (4): 60-85. 
[9] Herthorg MGL, Feskeens EJM, Hokum CH, Katan A. Dietary antioxidant flavonoids and risk of coronary heart disease. Journal De Zutphen Elderly Study. Lancet. 1993; 342: 10071011.

[10] Clairborne A. Catalase activities. Handbook of methods for oxygen radical research. Florida: CRC press; 1995. p. 283-4.

[11] Misra HP, Fridovich I. The role of superoxide anion in the autoxidation of epinephrine and a simple assay for superoxide dismutase. J Biol Chem. 1972; 25 (10): 247. 3170-5.

[12] Habig WH, Pabst NJ, Jakoby WB. Glutathione -S-transferase. The first enzymatic step in mercapturic acid formation. J Biol Chem. 1974; 249 (6): 7130-9.

[13] Sdelak J, Linday RH. Estimation of total protein, protein bound and non-protein sulfhydryl groups in tissue with ellman's reagent. Anal Biochem. 1996; 25 (1): 192-205.

[14] Ohkawa H, Ohishi N, Yagi K. Assay of lipid peroxidation in animal tissues by thiobarbituric acid reaction. Anal Biochem. 1978; 95: 351-8.

[15] Todorova I, Simeonovo G, Kyuchukova D, Dinev D, And GV. Reference values of oxidative stress parameters (*MDA< SOD and CAT) in dogs abd cats. Comp Clin Pathol. 2005; 13: 190-4.

[16] Al-Quraishy, Saleh, Mohamed A. Dkhil, Shaimaa R. Ibrahim, and Ahmed E. Abdel Moneim. "Neuroprotective potential of Indigoferaoblongifolia leaf methanolic extract against lead acetate-induced neurotoxicity." Neural regeneration research 11, no. 11 2016: 1797.

[17] Aguoru, C. U., C. Pilla, and J. O. Olasan. "Phytochemical screening of Xylopia aethiopica with emphasis on its medicinally active principles." Journal of Medicinal Plants Research 10.22 2016: 306-309.

[18] Ercal N, Treeratphan P, Lutz P, Hammond TC, Matthews RH. $\mathrm{N}$-actylcysteine protects Chinese hamster ovary $(\mathrm{CHO})$ cells from leadinduced oxidative stress. Toxicology 1996; 108 (1-2):
57-64. 19. Mahaffey KR. Nutrition and lead: Strategies for public health. Environ Health Perspect 1995; 103 Suppl 6: 191-6.

[19] Ahamed, Maqusood, and Mohd Kaleem Javed Siddiqui. "Environmental lead toxicity and nutritional factors." Clinical Nutrition 26, no. 4 (2007): 400-408.

[20] El-Masry T. A., Emara A. M., El-Shitany N. A. Possible protective effect of propolis against lead induced neurotoxicity in animal model. J Evolutionary Biol Res, 2011: 3 (1), 4-11.

[21] Gurer H, Neal R, Yang P, Oztezcan S, Ercal N. Captopril as an antioxidant in lead exposed Fischer 344 rats. Hum Exp Toxicol 1999; 18: 27 32.

[22] Pardeep Sidhu and Bimla Nehru*Lead Intoxication: Histological and Oxidative Damage in Rat Cerebrum and Cerebellum. The Journal of Trace Elements in Experimental Medicine 2004.17: 45-53.

[23] O. A. Adaramoye*, Bosede O. Popoo la and E. O. Farombi e Acta BiologicaHungarica on Effects of Xylopia aethiopica (Annonaceae) fruit methanol extract on $\gamma$-radiation-induced oxidative stressin brain of adult male Wistar rats 20101 (3), pp. 250-261.

[24] Adewale, O. B. and Orhue, N. E. J., Protective effect of Xylopia aethiopica fruits extracts on carbon tetrachlorideinduced nephrotoxicity in rats. J Exp Integr Med, 20155 (2), p. 105 .

[25] Adaramoye OA, Adedara IA, Popoola B, Farombi EO. Extract of Xylopia aethiopica (Annonaceae) protects against gammaradiation-induced testicular damage in wistar rats. Journal of Basic and Clinical Physiology and Pharmacology. 2010; 21 (4): 295-314.

[26] Adaramoye OA, Okiti OO, Farombi EO. Dried fruit extract from Xylopia aethiopica (Annonaceae) protects Wistar albino rats from adverse effects of whole-body radiation. Experimental and Toxicologic Pathology. 2011 Nov 1; 63 (78): $635-43$. 